\title{
Model Kebijakan Mapalus Kambitmas Dalam Menanggulangi Tawuran Antar Kelompok Pemuda di Kecamatan Malalayang Manado
}

\author{
Thelma Wawointana ${ }^{\text {a, }}$ * $^{*}$ \\ a Universitas Negeri Manado, Prodi Ilmu Administrasi Negara, Kota Manado, Indonesia \\ 1 thelmawawointana@unima.ac.id*;
}

IN F O A R T I K E L

Key word:

Policy Model,

Mapalus,

Kamtibmas,

brawl

\section{A B S T R A C T}

This study aims to determine the Mapalus Kamtibmas Policy Model in Tackling Brawls between Youth Groups in Malalayang District, Manado City. This study uses a qualitative method. The results of the study found that the Mapalus Kamtibmas Policy Model in tackling brawls between youth groups had not been implemented optimally in Malalayang District. This is because the government pays less attention to non-physical development, especially the character development of the existing youth, in addition to the lack of organizational platforms for fostering the easy generation and the lack of facilities and infrastructure for activities to channel youth hobbies such as sports and art activities. These factors are the causes of disputes and brawls between youth groups in Malalayang District. In addition, because of the influence of liquor due to the illegal circulation of liquor, the lack of supervision of the local government and the lack of attention from parents as well as the large number of youths who drop out of school and unemployment which causes frequent clashes and brawls. Then there are inequalities in society, especially such as economic problems, socio-cultural problems. Furthermore, due to rapid social changes in society as well as advances in information technology, social media/internet has resulted in closer relationships due to the existence of mobile phones (Hp) so that people can easily communicate.

\section{INTISARI}

\section{Kata kunci:}

Model Kebijakan,

Mapalus,

Kamtibmas,

Tawuran
Penelitian ini bertujuan untuk Untuk mengetahui Model Kebijakan Mapalus Kamtibmas dalam Menanggulangi Tawuran antar Kelompok Pemuda di Kecamatan Malalayang Kota Manado. Penelitian ini menggunakan metode kualitatif. Hasil penelitian menemukan Model Kebijakan Mapalus Kamtibmas dalam menanggulangi tawuran antar kelompok pemuda belum dilaksanakan secara optimal di Kecamatan Malalayang. Hal itu disebabkan pemerintah kurang memperhatikan pembangunan non fisik khususnya pembangunan karakter para pemuda yang ada, di samping itu kurangnya berperan wadah-wadah organisasi untuk pembinaan generasi mudah dan kurangnya sarana dan prasarana untuk kegiatan menyalurkan hobby para pemuda seperti kegiatan olah raga dan seni. Faktor-faktor inilah yang menjadi penyebab terjadinya pertikaian dan tawuran antar kelompok pemuda di Kecamatan Malalayang. Di samping itu pula karena pengaruh minuman keras akibat peredaran minuman keras secara illegal, kurangnya pengawasan pemerintah setempat dan kurangnya perhatian dari orang tua serta banyaknya pemuda yang putus sekolah dan pengangguran yang menyebabkan sering 
terjadi pertikaian dan tawuran. Kemudian adanya ketimpangan-ketimpangan dalam masyarakat, terutama seperti masalah ekonomi, masalah sosial budaya. Selanjutnya karena perubahan sosial yang begitu cepat di dalam masyarakat serta kemajuan teknologi informasi, media sosial/internet mengakibatkan hubungan semakin dekat karena adanya Hand phone ( $\mathrm{Hp})$ sehingga orang dengan mudah berkomunikasi.

Copyright (C) 2021 (Thelma Wawointana). All Right Reserved

\section{Pendahuluan}

Kebijakan publik sering dipahami sebagai instrument yang dipakai pemerintah untuk memecahkan masalah publik dan menyangkut kepentingan orang banyak. Pemerintah dalam hal ini menggunakan pendekatan rational choice untuk memilih alternatif terbaik guna memecahkan persoalan yang dihadapi masyarakat. Kebijakan publik menurut Dye adalah whatever governments choose to do or not to do. Menurut Dye bahwa apapun kegiatan pemerintah baik yang eksplisit maupun implisit merupakan kebijakan. Interpretasi kebijakan menurut Dye yaitu harus dimaknai dengan dua hal penting: pertama, bahwa kebijakan haruslah dilakukan oleh pemerintah, dan kedua, kebijakan tersebut mengandung pilihan dilakukan atau tidak dilakukan oleh pemerintah [1].

Menurut Harold Laswell dan Abraham Kaplan, kebijakan publik hendaknya berisi tujuan, nilai-nilai dan praktik-praktik sosial yang ada dalam masyarakat [2]. Randall B. Ripley menganjurkan agar kebijakan publik dilihat sebagai suatu proses dan melihat proses tersebut dalam suatu model sederhana untuk dapat memahami konstelasi antar aktor dan interaksi yang terjadi di dalamnya [3]. Adapun pandangan lain menurut Pasolong, pada dasarnya ada perbedaan antara konsep kebijakan dan kebijaksanaan. Kebijakan merupakan suatu rangkaian alternatif yang siap dipilih berdasarkan prinsip-prinsip tertentu. Sedangkan kebijaksanaan berkenaan dengan suatu keputusan yang memperbolehkan sesuatu yang sebenarnya dilarang berdasarkan alasan-alasan tertentu seperti pertimbangan kemanusiaan, keadaan gawat dan lainlain [4].

Randall B. Ripley menganjurkan agar kebijakan publik dilihat sebagai suatu proses dan melihat proses tersebut dalam suatu model sederhana untuk dapat memahami konstelasi antar aktor dan interaksi yang terjadi di dalamnya [3]. Selanjutnya, pandangan menurut Pasolong, pada dasarnya ada perbedaan antara konsep kebijakan dan kebijaksanaan [4]. Kebijakan merupakan suatu rangkaian alternatif yang siap dipilih berdasarkan prinsip-prinsip tertentu. Sedangkan kebijaksanaan berkenaan dengan suatu keputusan yang memperbolehkan sesuatu yang sebenarnya dilarang berdasarkan alasan-alasan tertentu seperti pertimbangan kemanusiaan, keadaan gawat dan lainlain. Kebijakan merupakan suatu hasil analisis yang mendalam terhadap berbagai alternatif yang bermuara kepada keputusan tentang alternatif terbaik. Sedangkan kebijaksanaan selalu mengandung makna melanggar segala sesuatu yang pernah ditetapkan karena alasan tertentu. Kebijaksanaan merupakan pengejawantahan aturan yang sudah ditetapkan sesuai situasi dan kondisi setempat oleh pejabat yang berwewenang. Dengan perbedaan defenisi tersebut di atas, maka seharusnya dalam implementasinya juga berbeda.

Kebijakan Mapalus kamtibmas sudah diimplementasikan melalui Pergub No. 8 tahun 2012 namun, hasil penelitian menemukan bahwa, Forum Mapalus Kamtibmas yang melibatkan aparat pemerintah desa/kelurahan, babinsa, Bhabinkamtibmas, dan tokoh masyarakat ini belum berperan secara optimal sebagai basis penciptaan nilai pelayanan publik di bidang kamtibmas. Penyebabnya, antara lain, ialah peran Pemerintah Daerah yang lemah dalam menginternalisasikan nilai-nilai lokal mapalus ke dalam formulasi dan implementasi kebijakan, serta faktor pendanaan/anggaran dan pengelolaannya yang kurang transparan, sumber daya manusia yang kurang memiliki kompetensi, dan sikap Pemerintah Daerah yang kurang responsif. Pentingnya adanya kerjasama antara Polisi, TNI, pemerintah desa/kelurahan dan masyarakat dengan mensosialisasikan nilai budaya lokal Mapalus, serta mereformulasi isi kebijakan, mengintensifkan pelaksanaannya [5].

Mapalus kamtibmas adalah semangat gotong royong, menghimpun dan melibatkan aparat keamanan Pemerintah desa/Kelurahan dengan mensyarakat untuk saling menolong dan bekerjasama secara aktif dalam mencari akar permasalahan, memecahkan masalah sosial serta mencari solusi dalam rangka mewujudkan kenyamanan, keamanan dan ketertiban masyarakat untuk terlaksananya program pembangunan, pemerintahan dan kemasyarakatan yang ada di desa/kelurahan.

Masalah kebijakam mapalus kamtibmas untuk meningkatkan keamanan dan ketertiban masyarakat serta pembinaan warga masyarakat khususnya generasi muda yang produktif merupakan jenis masalah sentral karena apabila program 
mapalus kamtibmas yang sedang diimplementasikan tidak dikembangkan berdasarkan kebutuhan kelompok sasaran atau secara spesifik untuk kebutuhan warga masyarakat yang sering terlibat tawuran yang sering terlibat tawuran, maka implementasi program akan cenderung berdampak pada: a) peningkatan jumlah kenakalan pemuda/remaja, b). peningkatan anak-anak yang putus sekolah, c) tingginya pengguna minuman keras, g) yang bertentangan nilai moral dan agama,

Penelitian ini bertujuan untuk mnganalisis kebutuhan model kebijakan mapalus kamtibmas dalam menanggulangi tawuran antar kelompok pemuda yang sering terlibat tawuran di Kecamatan Malalayng di Kota Manado. Pemasalahan tersebut apabila tidak diupayakan penanggulangannya sesegera mungkin akan berdampak pada stabilitas keamanan dan ketertiban masyarakat. Untuk itu perlu dioptimalkan upaya atau strategi melalui pengembangan model kebijakan Mapalus Kamtibmas di Kecamatan Malalayang.

\section{Metode Penelitian}

Penelitian ini dilaksanakan di Kecamatan Malalayang Kota Manado. Penelitian ini difokuskan pada model kebijakan Mapalus Kamtibmas dalam menanggulangi tawuran antar kelompok pemuda di Kecamatan Malalayang. Jenis penelitian ialah kualitatif dengan pendekatan studi kasus. Studi kasus karena sifatnya particularity (punya kekhususan), yaitu Kearifan Lokal Mapalus di Minahasa yang diterapkan dalam menanggulangi Tawuran aantar kelompok pemuda. Sumber data dalam penelitian ini dipilih secara purposive sampling, meliputi: Kepala Kecamatan, Kepala Kelurahan, Polisi (bhabinkamtibmas), dan TNI-AD (babinsa) dan tokoh masyarakat, tokoh pemuda yang ada di Kecamatan Malalayang. Sumber data dokumentasi yaitu bahan-bahan tertulis seperti Undang-undang, Peraturan Daerah, Peraturan Gubernur, bahan-bahan laporan dan arsip yang dianggap relevan, terutama dokumen-dokumen yang berkaitan dengan fokus penelitian. Teknik analisis data dilakukan pemeriksaan dengan menggunakan kriteria: a) derajat kepercayaan; b) keteralihan; c) ketergantungan, dan kepastian. Sedangkan teknik analisis data menggunakan analisis model interaktif [6].

\section{Hasil dan Pembahasan}

Suatu realitas kehidupan dalam masyarakat jika tanpa adanya pelayanan pemerintah, maka masyarakat akan melahirkan berbagai bentuk kekerasan dan kekacauan dan yang paling rentan generasi muda. Kehadiran pemerintah penting untuk mengatur dan melindungi serta memberikan fasilitas agar senantiasa dalam keadaan yang stabil maupun dinamis, sebab pada dasarnya manusia menurut Thomas Hobes adalah homo hominus lupus (manusia adalah serigala bagi manusia lain [7].
Pemerintah dalam melaksanakan fungsi utama yaitu: pengaturan (regulation) dan fungsi pelayanan (service), keterbatasan kemampuan pemeritah menimbulkan konsekuensi logis bagi didistribusikannya urusan-urusan sampai pada tingkatan masyarakat yang paling bawah [7]. Peranan pemerintah dalam peningkatan kehidupan berbangsa dan bernegara juga tergantung dari beberapa besar pemerintah memperhatikan generasi muda sebagai tongkat estafet dan agen perubahan, generasi muda sebagai penerus cita-cita bangsa dan sumber dan insani bagi pembangunan nasional. Oleh karena itu perlu ditingkatkan upaya pembinaan dan pengembangan generasi muda secara terus menerus dalam kerangka pembangunan nasional, pembinaan dan pengembangan generasi muda menuntut partisipasi dan tanggung jawab semua pihak dan untuk itu perlu ditingkatkan kebijaksanaan nasional tentang kepemudaan yang menyeluruh dan terpadu.

Pemuda dalam kehidupan bermasyarakat selalu dituntut peran aktif sesuai dengan kondisi dan lingkungan objektif dan subjektifnya oleh karena itu harus mampu menjadi subjek yang ikut menentukan masa depan bangsa dan mampu meberikan warna, serta nuansa yang mencerminkan kehidupan yang berdemokrasi. Oleh karena itu, organisasi kepemudaan harus diberikan kesempatan untuk berkembang dalam mewujudkan peran aktifnya, tetapi peran dan eksistensi generasi muda sangat tergantung pada independensi organisasi serta profesionalisme pengelolaan organisasi untuk menuju pada organisasi, untuk menuju pada organisasi yang otonom dan demokratis. Berangkat dari kesadaran akan pentingnya posisi, peranan dan potensi generasi muda dalam perjalanan sejarah perjuangan bangsa, maka pembinaan dan pengembangan organisasi kepemudaan haruslah diartikan sebagai keseluruhan upaya pendidikan politik baik secara sadar, berencana, terarah, teratur, berkesinambungan dan bertanggung jawab.

Banyak organisasi kepemudaan yang hadir di kota-kota dengan berbagai bentuk dan tujuan, dan banyak pula program yang dirancang oleh pemerintah untuk lebih meningkatkan kwantitas dan kwalitas dari organisasi kepemudaan yang ada. Namun, organisasi pemuda di desa dan kelurahan sangat kurang berperan. Beberapa waktu lalu ada organisasi kepemudaan seperti KNPI dan Karang Taruna namun sekarang ini organisasi tersebut tidak lagi efektif. Sangat penting bagi pemerintah untuk mengetahui apa yang menjadi kebutuhan dari pemuda saat ini, agar supaya peranan pemerintah dalam pengembangan organisasi pemuda saat ini menjadi efektif. Organisasi kepemudaan dengan fungsi minimumnya ialah pembentukan karakter generasi muda, kaderisasi, pengembangan bakat dan kemampuan. Oleh sebab itu di rasa sangat penting akan adanya peranan pemerintah untuk mengembangkan secara sunguh-sungguh organisasi kepemudaan yang ada di desa-desa dan kecamatan. Jangan sampai generasi muda yang ada tidak 
memiliki tempat/wadah dalam pengembangan diri, sehingga yang bisa terjadi adalah pemuda bersikap apatis dengan masalah yang ada di lingkungan sekitarnya bahkan dengan masalah kebangsaan.

Pemerintah belum berperan aktif dalam pembinaan generasi muda karena pemerintah lebih mengutamakan pembangunan fisik dibandingkan dengan pembangunan non fisik. Pembanguna fisik seperti jalan, jembatan dan irigasi menjadi prioritas pembangunan di Kecamatan Malalayang saat ini. Pembinaan generasi muda lebih berperan yaitu tokoh-tokoh agama, seperti Pendeta, gembala dan pelayan-pelayan khusus yang ada di desa. Disamping itu juga kurangnya perhatian pemerintah dalam pengadaan sarana dan prasarana kegiatan olah raga bagi masyarakat khususnya generasi muda seperti pengadaan lapangan olah raga untuk bola kaki atau lapangan bola volly serta berbagai perlombaan kegiatan olah raga dan seni di desa.

Banyak faktor yang menjadi penyebab terjadinya pertikaian antar pemuda di Kecamatan Malalayang. Menurut Soerjono Soekanto, sebabsebab terjadinya konflik antara lain yaitu: Perbedaan antar perorangan, perbedaan kebudayaan, bentrok kepentingan, perubahan sosial yang terlalu cepat di dalam masyarakat. Berdasarkan hasil penelitian ditemukan bahwa penyebab terjadinya pertikaian atau konflik antara pemuda di Kecamatan Malalayang karena pengaruh minuman keras yang sering dijual bebas. Adapula yang berpendapat bahwa konflik muncul karena adanya ketimpanganketimpangan dalam masyarakat, terutama juga karena masalah ekonomi, sosial budaya. Di samping itu juga karena adanya perbedaan-perbedaan kepentingan, kebutuhan, dan tujuan dari masing masing anggota masyarakat dan pemuda [8].

Selanjutnya ada faktor yang lain yang menjadi penyebab pertikaian atau konflik di antara pemuda yaitu karena perkembangan pengetahuan masyarakat atau perubahan sosial yang begitu cepat di dalam masyarakat. Pemuda sekarang ini berbeda atau tidak sama lagi dengan pemuda yang dahulu, dimana pada masa lalu pemuda di Desa/kelurahan merasa malu jika tidak ada pekerjaan karena kalau tidak sekolah lagi maka akan bekerja di ladang atau membantu orang tua tapi sekarang anak-anak muda baik yang masih sekolah maupun yang putus sekolah sama-sama sering terlibat kebut-kebutan di jalanan dengan motor. Sekarang anak-anak pulang sekolah langsung nongkrong-nongkrong di warung atau mondar-mandir dengan motor di jalanaan. Apalagi sekarang kemajuan teknologi mengakibatkan hubungan semakin dekat karena lewat hand phone (Hp). Orang dengan cepat berhubungan/berintraksi kemudian juga ada internet, jadi mereka sudah melihat contoh-contoh yang tidak baik di internet yang berakibat pada perilaku anak muda sekarang ini yang belum tentu sesuai dengan nilai-nilai budaya kita.

Kebanyakan orang tua sibuk bekerja sementara anak-anak dibiarkan dan tidak diperhatikan atau dilibatkan dalam pekerjaan. Anakanak sekarang lebih dimanjakan dengan memberikan kendaraan bermotor, Hp android sehingga tiap hari sibuk dengan medsos (media sosial) atau bermain game. Itulah sebabnya anak-anak menjadi egoisme dan tidak peduli dengan lingkungannya, Sehingga sering terpengaruh dengan lingkungan yang buruk. Di samping itu juga perlu ada wadah organisasi pemuda untuk pembinaan generasi muda seperti KNPI, Karang Taruna karena dengan wadah-wadan tersebut maka ada pembinaan generasi muda dan pemerintah dapat mengetahui apa yang menjadi kebutuhan dari generasi muda saat ini.

\section{Kesimpulan}

Model Kebijakan Mapalus Kamtibmas dalam menanggulangi tawuran antar kelompok pemuda belum dilaksanakan secara optimal di Kecamatan Malalayang. Hal itu disebabkan pemerintah kurang memperhatikan pembangunan non fisik khususnya pembangunan karakter para pemuda yang ada, di samping itu kurangnya berperan wadah-wadah organisasi untuk pembinaan generasi mudah dan kurangnya sarana dan prasarana untuk kegiatan menyalurkan bakat dan hobby para pemuda seperti kegiatan olah raga dan seni. Faktor-faktor inilah yang menjadi penyebab terjadinya pertikaian dan tawuran antar kelompok pemuda di Kecamatan Malalayang. Di samping itu pula karena pengaruh minuman keras akibat peredaran minuman keras secara illegal, kurangnya pengawasan pemerintah setempat dan kurangnya perhatian dari orang tua serta banyaknya pemuda yang putus sekolah dan pengangguran yang menyebabkan sering terjadi pertikaian dan tawuran.

Kemudian adanya ketimpangan-ketimpangan dalam masyarakat, terutama seperti masalah ekonomi, masalah sosial budaya. Selanjutnya karena perubahan sosial yang begitu cepat di dalam masyarakat serta kemajuan teknologi informasi, media sosial/internet mengakibatkan hubungan semakin dekat karena adanya Hand phone (Hp) sehingga orang dengan mudah berkomunikasi. Selanjutnya penyebab tawuran atau konflik di antara pemuda yaitu karena perkembangan pengetahuan masyarakat atau perubahan sosial yang begitu cepat di dalam masyarakat. Kemajuan teknologi informasi mengakibatkan hubungan semakin dekat karena lewat Hand phone (Hp) orang dengan cepat berhubungan/berintraksi. Kemudian juga adanya internet, mereka melihat contoh-contoh yang tidak baik di internet yang berakibat pada perilaku anak muda sekarang ini yang belum tentu sesuai dengan nilai-nilai budaya kita.

\section{Referensi}

[1] D. Indiahono, Kebijakan Public Berbasis Dynamic Policy. Analisys. Yogyakarta: Gava Media.

[2] H. D. Laswell and K. Abraham, Power and 
Society,. New Haven: Yale. University Press, 1970.

[3] B. Ripley, Bureucracy and Policy Implementation. Homewood: The Dorsey Press, 1982.

[4] Pasolong, Teori Administrasi Publik, Bandung: Alfabeta, 2010.

[5] "Peraturan Gubernur No. 8 Tahun 2012.".

[6] H. G. Ridder, M. B. Miles, A. Michael Huberman, and J. Saldaña, "Qualitative data analysis. A methods sourcebook," Zeitschrift fur Pers., 2014.

[7] S. H. Sarundajang, Babak Baru Sistem Pemerintahan Daerah. Jakarta: Kata Hasta, 2005.

[8] S. Soekanto, Sosiologi, Suatu Pengantar. Jakarta: PT Raja Grafindo Persada, 2000. 